Copyright (C) 2006 SAGE Publications London, Thousand Oaks CA and New Delhi

Vol 9(2) 223-242; 1367-5494 DOI: $10.1177 / 1367549406063165$ www.sagepublications.com

\title{
Paradise defiled
}

\section{The Bali bombings and the terror of}

national identity

\section{Jeff Lewis}

RMIT University

ABSTRACT The spread of global Jihadist terrorism was brutally announced in the 2002 Bali bombings. The attacks marked a significant moment in the relationship between Australia and Bali. The bewilderment characterizing

Balinese and Australian responses to the 2002 bombings is linked to processes of globalization and the 'de-bordering' of knowledge, most particularly as it resonates through locally constituted 'ideology', beliefs and identity. While for the Bali Hindu communities this cultural expressivity is located in Vedic mythology, rituals and principles, for many Australians it appears to be associated with various forms of political ideology and 'nationalism'. It is unsurprising that Australia's first commemoration of the bombing was iterated through a profound grief, rendered more acute by nationalism and national pride. It heroized the victims through the heroization of nation; the assailants were motivated by a desire not merely to destroy Australians and Australia but the very basis of the modern nation itself - freedom, democracy, justice and history.

KEYWORDs Bali bombings, bhuta kala, Gallipoli, nationalism, terrorism

In Balinese Hindu mythology the bhuta kala demons are not considered intrinsically evil, nor are their spiritual nemeses considered entirely wholesome. Rather, the dialectic of good and evil which characterizes Balinese Vedic culture is formed through an eternal interdependence: evil is not subjugated, redeemed or eradicated from the human body or spiritual world more generally since it is the predicate of good. The principle of rwa bhineda (two in one) conceives of good and evil in terms of a mutual identification which seeks merely to minimize the harm that evil may inflict on the living (and the dead). While in most instances the Balinese have been able to maintain rwa bhineda, even through the shock of rapid (post)modernization, the terrible events of 12 October 2002 have severely strained the island people's theological, ethical and social resolve. Like the revenge massacres perpetrated against Chinese and Partai 
Komunis Indonesia (PKI, Indonesian Communist Party) sympathizers in 1965, the Bali bombings left the local people raw and disturbed. The intensely devout and generally optimistic demeanour that the Balinese appear to have marshalled against the threatening excess of rapid social change seems to have been seriously strained by the bombings and their aftermath (see Hitchcock and Putra, 2004).

For Australians the shock has been equally overwhelming. While not a part of its sovereign territory, Bali has evolved certainly as a critical part of Australia's cultural imagining (Hamilton, 1990; Lewis, 1994; Vickers, 1990). In this sense, Bali is part of a cultural geography, a 'third space' as Henri Lefebvre calls it, which operates through at least two distinguishable cultural flows. First, Bali exists as an imaginary land-bridge connecting Australians to the region and the rest of the world. For many Australians, Bali constitutes the first interface of global contact which is not merely or exclusively generated by international popular culture: the journey to the extraneous territory of Bali represents a 'reaching out' into the world as opposed to being 'reached for' through domestic television, movie or music consumption. Second, however, this movement out constitutes its own countermove: that is, the reaching out is counterbalanced by an equally forceful movement towards self-interrogation or 'interiority'. The otherness of space provides a cultural resource for self-reflection and the exploration or expression of personal and collective identity. Australians' imaginative and bodily engagement with the cultural geography of Bali facilitates new forms of self-expression. At this second level, the journey to Bali is inevitably an expression of an overlapping imaginary where the self and the other are sustained by communion, contingency and new modes of cultural propinquity and change.

At this level, the notion of an integrated self becomes problematized, reflecting a broader and quite central issue for the process of globalization. As the movement across national and cultural borders creates these greater contiguities, the social knowledge that references these departures and modes of self-expression is also destabilized. As numerous commentators have pointed out (e.g. Castells, 1997; Featherstone, 1995; Held, 1995), the movement out towards greater cultural contiguities and modes of selfexpression seems both to problematize and foreground discourses of localism, including various iterations of the state and nation. Undoubtedly, the bewilderment that characterized Balinese and Australian responses to the 12 October bombings is linked to this 'de-bordering' of knowledge, most particularly as it resonates through locally-constituted 'ideology', beliefs and identity. While for the Hindu communities in Bali this cultural expressivity is located in Vedic mythology, rituals and principles, for many Australians it appears to be associated with various forms of political ideology and 'nationalism'. In this context, it is not surprising that Australia's first commemoration of the bombing was iterated through a 224 profound grief, which was rendered more acute by the motifs of 
nationalism and national pride. The commemoration, in fact, heroized the victims through the heroization of nation; the assailants were motivated, it seems, by a desire not merely to destroy Australians and Australia but the very basis of the modern nation itself - freedom, democracy, justice and history.

Just as George W. Bush had theologized the vengeance of Americans over September 11 in terms of 'infinite justice' (Lewis, 2005; Nacos, 2002; Silberstein, 2002; Tuman, 2003), so the Australian political leadership transformed the actions of the Bali bombers into a mode of cosmic evil perpetrated against innocent victims, the nation and ultimately 'all humanity'. Therefore Amrozi, one of the principal bombers, is demonized in the same way as Osama bin Laden and Saddam Hussein as the 'smiling assassin', the harbinger of all that is evil and offensive to human decency. The Christian remembrance service telecast across Australia served further to reinforce the mood of evangelism and moral outrage that has inscribed itself as a national crusade. These discourses provide additional cultural resources for those who would like to raise the bombings and terrorism more generally as an issue of Islamicism and national security. Of course, there is no diminishing the horror of the bombings, or the awful guilt of the perpetrators. But there is a need to confront the ways in which the atrocity is being contextualized, discussed and explained. The aim in this article is to examine the Bali bombings in terms of culture and identity, most especially around the problematics of nation and globalization processes. By way of clarification, the notion of globalization is used to refer broadly to the various directional flows associated with increasing cultural and national contiguity. Globalization implicates, therefore, the range of cultural meanings that are associated with financial and economic exchange, communications flows and the movement of people. Tourism, which is clearly implicated in the Bali bombings, remains a significant part of globalization flows.

\section{National psyche}

The Gallipoli disaster is invoked frequently as a precipitous moment in Australian cultural history. ${ }^{1}$ This strange and pointless colonial adventure, by which Australia confirmed its fidelity to British military and economic hegemony, has been shaped into a formidable motif for the popular imagining of nation and national identity. While the disaster exposes for many Australians the tragic deficiencies of an imperial system, over time 'Gallipoli' has assumed an even greater epiphanal power in the celebration of Australia as an independent, free and heroic nation. The paradox of constituting a national ideology around a fatuous and disastrous military failure has been noted often; as with the Eureka disaster' (ennobled as 'rebellion'), Gallipoli allows Australians to imagine an heroic imperial parturition, one which seems to valorize the status of 
the political victim. The invocation of Gallipoli during the Bali bombing and commemorations resonates with a similar ideological motive, a desire to transform the hideousness of the event into a discursive unity, a triumph of national valour. For the official discourses of the state, the Gallipoli-Bali analogue galvanizes the popular imagining against a common enemy: the disparate sensibilities, practices, ethics and ideas that constitute a social assembly are drawn together through an overarching political postulate, one that affirms the ultimate authority and validity of the state itself.

The poetic elegance of this unity, however, serves only to parenthesize its component parts - its absences. The very invocation of Gallipoli as a discourse which announces, as it obscures, the coercive authority of the state, necessarily dislocates the internal language wars that compose it. Thus, the seeming presence of this unity in the Gallipoli discourse immediately unravels as it seeks to identify itself $a s$ the state: that is, as an inviolable and absolute semiosis. The slightest glance at the internal composition of the signifier 'Gallipoli' reveals that it is composed of agonistic elements which may be read in a variety of ways. Thus, while Peter Weir's film Gallipoli (1981) might seem to synthesize the beach landing through a romantic valorization of Australian 'identity', nevertheless the composite elements continue to exist beyond the borders of a propagated textual (and national) unity. There remains, for example, a series of distinct tensions around the ethical and ideological validity of empire, nation, class, gender, ethnicity and even violence itself. As Fredric Jameson (1981) noted some time ago, these agonisms and textual elements pre-exist their withdrawal into the absolute and constituted synthesis of 'interpretation' or analysis (the secondary text). That is, the multiply-layered and infinitely complex elements that made up the original experiences of Gallipoli are reduced and synthesized in order to create Weir's film text; the film is then reduced further as it is interpreted by viewers and critics. This flow to synthesis, however, is subverted by the pre-existence of the elements that constitute it. The synthesized version of Gallipoli, which might heroize Australia and its culture, must confront other agonisms - for example, the military élite which functions through all three nations to sacrifice the lives of common class soldiers as they protect their own class interests; Australia's military aggression, racism and Orientalism; an imperialism which validates its territorial claims through brutal coercion; a patriarchy which affirms power in masculine violence and militarism; death and maiming, which become the shared borders of individuals without regard to nation, ethnicity, class status or gender; and a banality which exists as a neutral underpinning to the grand projects of ideology.

However, these alternative linguistic tropes are themselves engaged in a battle for primacy. Weir's film - indeed all representations of Gallipoli - must struggle internally and externally against the agonistic potential of 
alternative meaning and semiotic dispersal. Of course, hegemonic social groups seek to 'enlist' Gallipoli in the assertion of their own particular interests and ideological order. For a range of reasons, Gallipoli appears to be particularly susceptible to this sort of discursive conscription, combining as it does the possibility of heroic ascent with a (post-colonial) victim consciousness that rails against an externally imposed iniquitous authority. This conflux of opposite potential seems to facilitate the broader convergence of state interest and popular imagining, a necessary precondition for the maintenance of an essentially hierarchical social system. And while this symbolic order is not as implacable as Althusser has claimed, nevertheless it draws together its contingent agonisms into a 'presence' that allows for the subjugation of potential disorder. Paul Virilio (2002) has suggested, in fact, that this subjugation has been pursued actively by a military class whose historical project has been the domination of the remainder of humanity. While Virilio's claim may seem excessively totalistic, one can say with some certainty that the state itself represents the latest incarnation of social violence and coercion - militarism is the constant of an hierarchical order which establishes itself in the cartography of nation and empire. Concepts such as national 'identity', 'consciousness' or 'psyche' (Anderson, 1991) are part of the grand signification of modernization.

In Australia, this process of becoming modern is necessarily implicated in the formation and expression of militarism. Having been established for principally military and strategic reasons, the colonies of Australia participated in a number of extraterritorial campaigns well before federation and Gallipoli. Under the imperial banner, colonial troops fought against Zulus, Sudanese, Boers, Chinese Boxers, Indians and Maoris. Since federation, the Australian military has fought against a range of Muslims and 'Orientals' in Afghanistan, Iraq (twice), Japan, Korea, Kosovo and Vietnam. While Australia's sovereign territory has been threatened only once since British settlement (during the Second World War), it has continued to centre its security policies on a perceived threat, most frequently associated with Asia and Islam - China, Indonesia and North Korea. Not surprisingly, this militarism has both propagated and responded to a somewhat diffuse sense of national anxiety, appending itself to the perceived greatness of 'natural' allies, the United Kingdom and the United States. This 'great and powerful friends' foreign policy has expressed itself culturally and psychologically as a sense of presence within the perpetual imagining and re-imagining of an East-West divide.

As it is forged into contemporary discourses, Gallipoli seems to reinvigorate this otherwise precarious 'presence' constantly. For example, on the commemoration of the Bali bombings, the premier of Victoria, Steve Bracks, made explicit the link between Gallipoli and the national psyche. Terrorism becomes the new unnamed enemy of the state and the values which Gallipoli represents: 
Not only did it bring terrorism to our doorstep, it has led to the indelible mark on our national psyche ... Like Gallipoli, it's my hope that the lasting legacy of Bali will be a peaceful and unifying one. (quoted in Dubecki, 2003: 15)

Within a resurgent East-West divide, Bracks' reading of history clearly situates the perpetrators of the bombing with the adversary in the Gallipoli context. The conservative commentator, Piers Akerman, invokes the spirit of Gallipoli and the 'unifying' effects of nation in his account of the commemoration, published in Sydney's Sunday Telegraph:

Next Sunday, we will mark the first anniversary of the Bali bombing, Australia's shock introduction to the nightmare world of Islamic terrorism . . . The scars are still fresh. There's no doubt we are a vastly changed nation. Although Bali can't be ranked with Gallipoli on a scale of national disasters, nor the losses compared with the wholesale slaughter of World War I, the raw immediacy of the coverage ensured that images of survivors stumbling from the burning ruins of the Sari Club have been seared into the national psyche. (Akerman, 2003: 2)

This radical inscription on the national psyche is as much a 'loss of innocence' ('The No-Longer-Lucky Country', 2002: 32) as a realization that: 'As Australians, we are faced with the reality of having the world's largest Islamic nation on our doorstep . . . [with] a highly volatile system of government' (Akerman, 2003: 2). Whereas the Turks are situated safely in another hemisphere, the contiguity of Indonesian Islamists poses a more immediate and inescapable threat: it is the mere fact that these are 'Muslims' in our near north which constitutes a significant danger to Australia's national security.

This 'threat' is identified also by the Zionist Federation of Australia, whose own polemical interests were clearly stimulated by the bombings. Not long after the Bali attacks the Federation Newsletter published the following poem:

You hurt us bombing Bali, but we can take the pain,

But if you think you'll beat us, then you can think a-bloody-gain,

We battled at Gallipoli and we fought the bloody hun,

Of all the arseholes we've had to face, you're just another one. (Holland, 2002)

Thus the Jewish diaspora is mobilized into the mysterious convocation of a national unity that translates Islamic militantism into the common threat. In this sense, Gallipoli symbolizes a shared destiny in which the complex diversity of individuals and communities in Australia are galvanized through a unitary imaginary, most particularly as it is articulated through an invigorated East-West (Muslim-West) divide. The Bali bombings are another iteration by which nation can express itself against 
the agonistic counterflows of diffuse interests and individual perspectives and values.

\section{The age of terror}

Many commentators locate the period following the French Revolution as the etymological source of political terror. According to Walter Laqueur (1987, 2003), the 'reign of terror' marks a moment in the evolution of modern politics and the modern state when raw power dominates the rule of law. While Hoffman (1998) has identified significant changes to the ways in which the concept of 'terrorism' has been used since the 18th century, nevertheless we can see some continuities between the reign of terror and what Laqueur calls the current 'age of terror'. In particular, the violence of the Revolution quickly shifted its target from the aristocracy to other citizens whose values or social allegiances may have transgressed the perceived interests of the self-constituting ruling party. Ordinary citizens were subjected to perpetual menace, including the removal of property and the threat of torture and death. Ideology and ethical systems were shuffled around as citizens sought to align themselves with any postulate or political group who could secure them against this brutality. This enjoinment of politics and violence actually percolated the dangers throughout the community; terror became a political instrument that combined persuasion with occasional and actual violence.

Of course, there is nothing new about this deployment of threat and violence in political management, most especially by rulers over subjects or warriors over workers. However, the emergence of the modern state and notions of citizenship demonstrates how power can be broadly dispersed through an increasingly urbanized mass society. Foucault (1991) has identified this shift in modes of social management, suggesting that the modern state, which is created through hierarchical systems of material exchange, has evolved highly precise strategies (technologies) of control that maintain order. Somewhat paradoxically, this evolving process of a widely-dispersed system of 'governmentality' may derive in fact from the embryo of threatened disorder by which citizens access and deliver power through terror. The French Revolution illustrated how the relationship between state and citizen is underscored by a mutual predisposition of violence: political thinkers from Auguste Comte to James and John Stuart Mill, Thomas Carlyle and Matthew Arnold recognized that the potential for 'democracy' and 'representation' was necessarily and precariously balanced through the violent potential of this relationship. Social and political order must rest upon a fulcrum that balances authority and access, state and citizen. In this sense, Hoffman's view that terror has moved from the state to the populace is dubious since, as is argued here, all power in the modern state is effected through a process of exchange. The radical irruption of 'social order' by the secretive forces of terror is already 
inscribed in the notion of statehood: democracy becomes part of a fluid motion of orderly and disorderly engagements of power, threat, persuasion and coercion.

Democracy, therefore, enshrines the rights and freedoms of the citizen within a political context of vulnerability: the citizen is vulnerable to the violence and persuasion of the state, as the state is vulnerable to the violence and freedoms of the individual (Lewis, 2003). It is precisely this vulnerability which draws terror from its historical and discursive shadows as a military and political instrument of violence. Clearly, a democratic order that privileges hierarchies of obedience and control necessarily marginalizes specific perspectives, discourses and social formations. The notional 'majority' masks its absent other by excluding contrary views, especially radical views, from its discursive ambit. Political violence in Fiji, India, Northern Ireland, Palestine, Sri Lanka and the US (Waco, TX) are all associated with the limits of a democratic system by which the state and its 'majority' seek to impose their will over aggrieved social groups who feel their views are not being adequately 'represented'. At this point, the distinction between political and military strategy becomes functionally blurred.

In a (post)modernizing world characterized by broad flows of people, information, imagery, products and finance, the problems associated with the 'representation' of political interests are significantly exacerbated (Castells, 1997; Held, 1995; Zolo, 1997). The targeting of the US in the September 11 attacks is clearly related to the problematics of US cultural, military and economic hegemony which, of itself, is part of the outward expression of nation and its hierarchical systems, including the ideology of liberal democracy. This internationalization of the 'democratic state' carries with it the same inscriptions of power, 'majority' and vulnerability of citizens. However (and as I have explained in greater detail elsewhere, see Lewis, 2002), the internationalization of national hegemony will marginalize further the interests, rights, needs and political aspirations of other discourses and social groups who do not necessarily subscribe to the dominant order. At this level, the globalization of economy and culture exposes the host of internationalization to the terror of political violence. The deficiencies of democracy that are evident within nations become extraterritorialized, as national hegemonies seek to maximize their constituent advantages within a globalizing hierarchy of interests. As it goes out into the world, liberal democracy assumes its primacy over all other ideologies and interests.

Specifically, while these marginalized groups are encased within the global influence of the US, they are neither 'represented' in US decisionmaking nor the electoral processes that affirm their legitimacy: they are not part of the US 'electoral' ambit. This globalizing of influence without a commensurate globalizing of representation (Zolo, 1997) is clearly problematic. Various international and national military and political codes 
have sought to neutralize its potential dangers by criminalizing specific modes of political opposition: violent opposition, particularly that which targets 'non-combatants', is situated within a legal and juridical discourse. In US law, for example, terrorism is defined as 'premeditated, politically motivated violence against non-combatant targets by subnational groups or clandestine agents' (22 USCA 2656 (d) 1990, supp. 2000). This definition is clearly marking the illegality of 'sub-national' groups against the legitimacy of nation and a state-based rule of law, most particularly where the state is founded on democratic principles and universal codes of human rights (Laqueur, 1987).

Noam Chomsky (2001) argues, however, that the US's own official strategy of 'low intensity warfare' as it is explained in various military manuals, including the 'US Code', actually constitutes a form of strategic terrorism. This strategy includes 'coercion of civilians', which may result in death and the destruction of social and material infrastructure such as transportation lines, communications, hospitals and so forth. As Chomsky points out, this is precisely the strategy adopted by those who destroyed the World Trade Center. Moreover, there can be little doubt that covert and overt CIA operations in places such as Nicaragua and the Sudan fit clearly within the US's own definitional boundaries of 'terrorism'. As many commentators have noted, the identification of terrorism and terrorists is largely a contingency of power: those groups with greater access and control over discourse and meaning-making, especially the mass media, are more likely to have their perspectives generated and heard. The hierarchical system and political privileging of 'majorities' facilitate the propagation of sectoral interest, including the privileged distinction between 'terrorist' and 'freedom fighter'. The American 'War on Terror' is declared by the victims of the violence against the perpetrators. Not surprisingly, the accusation has been returned by those who have suffered during American reprisal attacks against Afghanistan and Iraq. Similarly, both the Palestinians and Israelis are accusing each other of a terrorist violence which targets 'innocent citizens', including women and children.

Brigitte Nacos (2002) argues that a critical dimension of this process of labelling is communicational (see also Laqueur, 1987, 2003; Tuman, 2003). Following Sisela Bok's (1998) examination of media violence as crimebased entertainment, Nacos argues that terrorists are not so much concerned with the victims as the informational impact of their deeds. The terrorists are not arbitrary or motivated by petty material gain; rather, they seek to communicate specific messages through the mass mediation of brutal and frightening details (Nacos, 2002). In this way, the mass media is absolutely implicated in the political activities of the terrorist organization:

The starting point is the notion of mass mediated terrorism and its definition as political violence against noncombatant/innocents that is committed with 
the intention to publicize the deed, to gain publicity and thereby public and government attention. (Nacos, 2002: 17)

This emphasis on the significance of the media acknowledges the substantive link between material and discursive dimensions of political violence and the exercise of power. As has been noted previously, the status of citizen and state are mutually contingent, forming around the respective possibilities of violence, coercion and persuasion. In this context, all violence is persuasive and all persuasion carries with it the potential for violence, threat or terror, since it ultimately references a violent state and its overarching assertion of authority. Nevertheless, the regulatory regime, which would parade the state in terms of a democratic legitimacy, is inscribed with the 'vulnerability' of the citizen-to-state and stateto-citizen. Questions as to whether the state and its vast machinery of violence can commit acts of terror become largely redundant. Indeed, in Virilio's terms, the threat of violence is the critical foundation of the state itself; notions of legitimacy and illegitimacy are less relevant than the history of institutionalization which continues to ennoble aggression as it perpetuates an imaginary of violence that is represented through a broad range of mediated discourses. Therefore, the ubiquity of violence in the media has become a matter of cultural exigency, providing the rhetorical resources not merely for the authorization of social order but for terrorism as a generalized mode of political expression (see Tuman, 2003).

Thus the mass media is not so much an arm of the state, as Chomsky and others have claimed; rather, it is the conduit for the exchange of persuasive perspectives and discourses along with their imaginary of violence. Jean Baudrillard has suggested that, in fact, our entire reality has been transformed by the proliferation and ascendancy of mass-mediated imagery. If this is the case (and one suspects that it is), then the violence that is now a mainstay of popular mediated culture, particularly as it is generated through American television and cinema, conditions a hyperreal consciousness which anticipates a perpetual volition of socially constituted threat. I have argued elsewhere (Lewis, 2002, 2003) that this mode of televisual culture concentrates the possibilities of human expressivity through the formation of the world-as-picture. Extending Heidegger's arguments about the world picture, it is suggested further that the presentation of televisual violence is an inevitable corollary of televisual politics, whereby the spectacle of polemic (Debord, 1995) inscribes itself on the popular consciousness. At this level, politics is always associated with the popular imaginary and popular culture (music, film, television, narrative) and is not located simply in institutional processes, debates and rationalities. Political debate, including debate around warfare and terror, is generated through visual stimuli and a symbolic ordering that interpolates as it elicits public engagement and judgement. The mediation of terror is generated fundamentally through this televisual public sphere. As Susan 
Carruthers (2000) has noted, the successful waging of war in a modern democratic state is precisely a contingency of this tripartite engagement of state, mass media and public opinion: the definition and identification of 'terrorism' is critically bound to its hyperreal democratic cultural context.

\section{Globalization and the spirit of terror}

Baudrillard (1995) has argued famously that the Gulf War did not take place. While this claim outrages many critics (e.g. Norris, 1992), in essence Baudrillard is suggesting that the American attack on Iraq should not be called a 'war': first, because the two sides of the conflict were so unevenly matched; second, because the official US military imaging of the 'attack' profoundly distorted the event, constituting it for world TV audiences as a 'war without death'. Following the September 11 attack on New York, Baudrillard broadened these arguments, suggesting that American domination of the hyperreal global 'system' was of itself the essence or spirit of terrorism. This global domination manifests itself primarily through the hyperreality of media communications, but is critically linked also to American military and economic primacy - this is the essence of globalization. This is not merely to say, as Noam Chomsky and others might, that American foreign policy contributed to the attack on New York; it is rather to suggest that the actual existence of a single and unitary global superpower constitutes its own predicate of violence. Foucault has said something similar, of course, in arguing that power generates its own inevitable opposition. However, for Baudrillard, it is the sheer singularity and mass of this power which of itself cannot be directly and genuinely opposed, altered or exchanged. The terrorism that assaults the megapower of US global domination is merely reactive, an inevitable response to singularity itself:

To a system whose very excess of power poses an insoluble challenge, the terrorists respond with a definitive act which is also not susceptible of exchange. Terrorism is the act which restores an irreducible singularity to the heart of a system of generalized exchange. All the singularities (species, individuals and cultures) that have paid with their deaths for the installation of a global circulation governed by a single power are taking their revenge today through this terroristic situational transfer. (Baudrillard, 2002: 9)

Like particles of dust being cast up by the monster's own feet, this terrorism may assault the eyes of globalization. In this sense it is 'terror against terror', although without the density of ideas or ideology. Therefore, in a hyperreal cultural condition the triumph of globalization leads inevitably to a battle against itself. This 'Fourth World War', as Baudrillard defines the current agonisms, is not a battle of ideologies or a clash of civilizations (Huntington, 1996), but rather it is the world (or globe) 
battling against the inevitable flows of globalization. In other words, it is a world system in which power is both feeding on and attacking itself - 'if Islam dominated the world, terrorism would rise against Islam' (Baudrillard, 2002: 12).

The spirit of terrorism, therefore, is to be found in its momentous and inclusive progression. While other commentators concern themselves with the details of political or military conflict, Baudrillard's more ontological enquiry seeks to expose the force that lies behind US globalization. Achieving an even more theological epiphany, Baudrillard argues that good and evil work simultaneously towards the same political ends:

We believe naively that the progress of Good, its advance in all fields (the sciences, technology, democracy, human rights), corresponds to a defeat of Evil. No one seems to have understood that Good and Evil advance together, as part of the same movement. The triumph of the one does not eclipse the other ... Good does not conquer Evil, nor indeed does the reverse happen: they are at once both irreducible to each other and inextricably interrelated. (Baudrillard, 2002: 13)

Baudrillard may well be accused of hyperbole and excessive generalization. Even so, these arguments derive from the author's consistent interest in Gnostic-Manichean philosophy. According to Jonathan Smith (2004), Baudrillard's approach distinguishes terrorism as a form of 'pure appearance' - the manifestation of what he calls 'hyperreality' in his earlier writings. This pure appearance resembles the 'pre-consciousness' in Lacanian theory, although for Baudrillard it is the pure appearance of the 'ephemeral moment in which things take the time to appear before taking on meaning or value' (1987: 88). Baudrillard argues that it is through this state of pure appearance that humanity is exposed to a profound moral and spiritual ambiguity. Terrorism, which merely responds to the excess of globalization, constitutes a form of pure appearance, at least in as much as it is a functionally communicational act that has neither substance nor clarity.

Baudrillard's ideas have a distinct relevance to our discussions here, most particularly in terms of the relationships between state and citizen and democracy and violence. The positive effects of (post)modernization seem inevitably to implicate negative effects, including a violence that is inscribed in the actual legitimacy of the state and processes of economic and cultural globalization. More broadly, however, the Gnostic notion of a 'corrupted' cosmos that is bound perpetually to the wheel of moral and spiritual combat clearly parallels the Hindu concept of rwa bhineda. As was noted previously, the Hindu cosmos is characterized by an unceasing conflict between the two often indistinguishable forces of good and evil.

At this level, the bewilderment experienced by the Balinese during and 234 after the 12 October bombings might be associated with Baudrillard's 
reading of globalization and the implacable contiguity of Manichean intensities. Thus, while the Balinese have experienced considerable pain over the bombings, this pain has not expressed itself as vengeance against 'evil' Muslims, even though this was widely feared and predicted by many western commentators (see Connor and Vickers, 2003). As I read it, the rather subdued and even apologetic demeanour of most Balinese reflects a continuing fidelity to rwa bhineda as well as an extraordinary adaptability which has characterized them throughout the period of (post)modernization. Unlike the US, UK and other forces that invaded Afghanistan and Iraq, the Balinese were not prepared to sacrifice innocent Muslims for the sake of revenge against terrorist perpetrators. To this extent, they seem to recognize that evil itself is neither so easily defined nor contained and that being Muslim was not tantamount to being guilty. Perhaps this insight into the complexity of evil also explains partly the absence of looting during the aftermath of the bombings. Despite the relative poverty of many Balinese and the extreme vulnerability of many of the shops in the Legian Street area, the Balinese devoted themselves to assistance, reparation and libations that might protect the community against further outbreaks of evil. The capture and trials of the suspected perpetrators were part of a precise strategy that would constrain evil effects.

This is not to suggest that the Balinese are not capable of considerable violence; on the contrary, Balinese history is replete with narratives of extreme violence and brutality (Cribb, 1990) which belie the notion of 'Bali harmony' - a government and community-sponsored discourse designed to promote Bali as a safe and 'spiritually transcendent' tourist destination (Lewis, 1994; Reuter, 2003; Vickers, 1990). Even so, the potential for violence, most particularly an outbreak of latent but ongoing ethnic and community tensions, has been restricted largely to a few skirmishes and grievances over internal migration (Hitchcock and Putra, 2004; Lewis and Lewis, 2004; United Nations Development Program (UNDP), 2003). Certainly, the presence of significant numbers of internal (mostly Muslim) migrants seeking work in the tourism areas of Kuta-Legian has compounded the historical sense of isolation experienced by many Hindu Balinese (Lewis and Lewis, 2004). However, rather than express these anxieties through a violent xenophobia, the Balinese appear to have drawn together the seemingly opposing effects of tradition and (post)modern cultural and economic pragmatism. In particular, rwa bhineda has provided a forum for the Balinese in which the forces of evil can be engaged and contained without the expectation of victory or absolute resolution.

Thus, the Balinese response to the bombing expresses an identity that is mediated through the ethical and theological principles of a substantial cultural heritage and the evolving effects of (post)modernization. Whatever their own potential for violence, it is largely constituted through this interface of history and contemporary conditions. As if to test 
Baudrillard's theory, the absorption of Balinese culture and geography into American-dominated globalization has reconfigured the 'meaning' of Bali in terms of the symbolic capital of international tourism. Accommodating over 1 million international tourism arrivals a year, Bali is imagined frequently as a paradise of aesthetic, spiritual and sensuous liberation (Vickers, 1990). For Australians, in particular, Bali has come to represent a propinquity of' 'Oriental' pleasure and self-reflection, a place in which the exotic 'other' can be experienced through various gradients of immersion. Clearly, Paddy's Bar and the Sari Club were bombed not merely because they were 'soft' targets, but because they symbolized the globalizing effect of commodified imagining. The global capital and cosmopolitan lifestyle, which are symbolized in the 22 nationalities of the dead, have become the ensigns of moral and ideological decadence for the terrorist attackers. There is a dramatic dissonance between the imagining of the victims and that of the perpetrators. These mostly 'first world' citizens, trapped in the throes of their pleasure, become ideal targets for organizations such as Jamaah Islamiyah because they are so entirely oblivious to the violence upon which their privilege is founded.

While Jamaah Islamiyah had focused its attacks previously on Indonesian Christians (UNDP, 2003), the switch to western targets and Bali was based upon the militants' belief that the island represented the excesses and degradation of westernization in Indonesia. The death of Balinese workers in the nightclubs was justified because the Balinese had become servile to western decadence. However, from the other side, the Balinese were barely visible to western governments, public officials and media reports which tended to generalize or obscure the fate of the Balinese in terms of a general Indonesian threat. This reading tended to embed the Balinese within a broader conflation of Jamaah Islamiyah's estimated 3000 operatives with a population of 200 million Indonesian Muslims: the pure appearance of the Balinese in the Australian imaginary became a kind of 'disappearance' within a broadly articulated fear of the northern threat. In fact, the Balinese exist in a realm that is slightly between and beyond the propagated distinctions of Islam and the West. While observing the imperatives of a Muslim-dominated statehood, Bali has been conscripted into the global economy of international tourism. Through the simultaneous movement of national integration and postmodern globalization, Bali has had to mediate its own Hindu localisms through an accommodating and flexible cultural evolution (Hitchcock and Putra, 2004, Lewis and Lewis, 2004). Experiencing both the pleasures and vicissitudes of rapid social change and (post)modernization, Bali and Balinese identity are created through a continuing dialogue of good and evil effects.

In fact, Bali has never evolved a 'nationalist' perspective, since it has been largely an indifferent conscript into the Javanese national hegemony (Connor and Vickers, 2003). The localism that it expresses is refracted 
through the multiple prisms of globalization. This transformation of opposing movements more clearly parallels the Australian experience and is perhaps one reason for the relative comfort that has characterized its respective postmodernizing experiences. At the level of personal interaction, cultural exchange and business, the relationship between the Balinese and Australians has been remarkably positive. Paradoxically, perhaps, the violence perpetrated by Jamaah Islamiyah might seem to affirm the contiguity of the Australian tourists and their Balinese hosts, not merely because they were occupying a common cultural space at Paddy's Bar or the Sari Club, but because they were both agents of a new globalizing cultural order - or disorder. For all their significant differences, the Balinese and Australians share in the effects of cultural debordering and fragmentation, which implicates the problematization of notions of nation and national psyche. The terrorist attacks associated with al-Qaeda and Jamaah Islamiyah are more than a 'clash of fundamentalisms' as they are described by Tariq Ali (2003). They are an attempt by the contending powers to purify the cultural flow, to (re-)establish a singularity that sustains a dominant directional order against the counterflow of fragmentation. Just as the proponents of the modern state set out to fix the flow of culture against the fragmentary potential of local communities or individuals, so the forces of globalization seek to move the direction of culture towards its own centre, against dispersal and a profusion of counterflows. The 'clash' is not merely of one version of globalism against another, US liberalism against Islamic fundamentalism. It is also a clash between the superflows of domination and the infinitude of alternative human potential which also clashes within itself. In this sense, terrorism has no centre but is a progression of human expressivities or language wars that are predicated on the legitimacy of violence (Lewis, 2005).

The nation remains forceful within a globalizing system only inasmuch as it serves the interests of globalization itself: that is, when the instrument of violence that is inscribed in the relationship between the state and the citizen can be mobilized in support of domination. Against the fragmentary potential of individuals with open identities, the nation-state imposes its will in a discourse of 'value', especially economic value. Thus, the proponents of economic globalization are seeking to dissolve the inevitable sideeffects of their own internationalization, most particularly the formation of new cultural contiguities and discourses of fragmentation and dispersal. The Balinese and Australians who have worked most comfortably together in forming some of these new discourses are forced continually to reconcile them against the 'superflows' of a global domination and the violence inscribed in state and citizenship. For the Balinese, the symbology of Pancasila might be equated to the historical celebrationism of Gallipoli, both of which glorify the unity of nation within the shrine of violence, warfare and death. 


\section{Conclusion: the forge of national identity}

Tom Nairn has suggested that Australia's grief over the bombings is shaped, at least in part, by an incomplete identity. According to Nairn, Australia has 'no history' and so its identity is largely unformed:

The communication of a nation's victims is always a mobilisation of the past, to reinforce the future flowing out of it. But where the past 'we' remains indecisive or questioned, the mourning is also a kind of question-mark. In Australia it asks who the bereft now want to be, or to become. (2002: 3)

Nairn goes on to ask whether globalization will intensify or abrogate the need for the solidification of identity, most particularly for a nation which is barely embryonic. While Nairn overlooks the complexity of the hybrid national history of Australia, nevertheless the questions that he poses are pertinent for both Australia and Bali. In fact, while the Balinese might seem to have a relatively homogenous cultural heritage, clearly the coalescence of the cosmopolitan lifestyle and the village social reality, as Connor and Vickers (2003) describe it, has pluralized the islanders' individual and collective identities almost beyond recognition. While tourists from Australia and elsewhere may continue to seek the 'authentic' Balinese Vedic experience occasionally, even this authenticity is a hybrid of propagated imaginaries forming through village rituals and a hotel economy. More than anything else, the cultural exchange between Australia and Bali has contributed to even broader hybridizing forms. In this sense, the Bali bombings were as much an expression of mutual ongoing cultural inscribing as they were an example of a new East-West cultural divide. The language wars that underlie all culture and become spectacularly exigent in periods of significant propinquity and rapid change represent a broad field of shifts, battles and realignments: the horror of the bombings emerges not just from the maiming and death but also in the parallel shock of its inevitability.

It is perhaps for this reason that the commemoration of the Bali bombings and the persistent invocation of Gallipoli seems so incomplete. Of course, for the survivors and family members who were directly affected by the bombing, the official commemoration ceremony in Bali must have seemed a significant public acknowledgement of their grief, bringing with it a sense of solidarity, community support and sympathy. These things are very important. But in the nationally-inscribed gestures, there was something critically missing. Perhaps in the various Hindu and hybrid community ceremonies that have been held almost continually since the bombings, including ceremonies conducted by the respective surfing communities, there emerges a stronger sense of parallel destiny, a shared humanity that is not deluded or by the imaginary primacy and purposefulness of state, nation and globalization. Perhaps, in fact, the 
better part of globalization - that more tolerant and mutually informing cultural engagement and interflow of sensibilities - seems to have been expressed through an ongoing expiation of the good-evil compound. It appears that the idealism that brought many artists, backpackers and surfers to the island in the 1960s and 1970s seems resurgent in these ceremonies and other modes of community support. While official discourses in Australia continue to ignore the plight of the Balinese and while highend tourism has largely deserted the island, the lower-walled Australian travellers are resuming their occupation of an idealized, hybrid culture.

My son had been a regular visitor to the Sari Club not long before the bombings. When I imagine the horror of the event, I think very directly of our own extraordinary good fortune. But I also feel embittered by the invocation of Gallipoli. I wonder how this trajectory of violence might be interrupted and I think with deep grief about the people who have been maimed, killed and bereaved. I think of the terror of the victims in the last few moments in that hideous inferno. And I think of the shock and poverty of the Balinese people themselves and the ways in which their own cultural integrity has been sullied. Beyond these sufferings, however, I wonder whether we are capable of looking squarely at the violence that is fundamentally inscribed in the state and its relationship with citizens, because it is this violence more than anything else which threatens our security. It is a violence based on a hierarchy of value, an ordering that delimits individuals and social groups, creating formidable allegiances of discursive and material power - exchanging the privilege of the few for the exclusion of others. The invocation of Gallipoli might make sense if the flaws of this hierarchy of allegiance were to be exposed against the imagining of violence. If this violence were exposed, then the better part of globalization might depose intrinsic and fallacious commemorations: events such as Gallipoli and the Bali bombings would be exposed as tragic consequences of statehood and its new global expressivity. In this case, we would view the perpetrators of the bombings in the same light as all proponents of extreme violence, including the state. If this were possible, then oppressive policies and violent reactions may be preventable.

\section{Note}

1. The military campaign at Gallipoli, on the coast of Turkey, took place in the First World War. The Allied command decided to open a new front against the Germans and to neutralize the military capacity of the Ottoman Empire (Turkey, significant parts of the Balkans and the Arabian subcontinent, including Israel, Yemen and Iraq). The Australian and New Zealand forces operated under the command of the British; in the two phases of the campaign, April and August 1915, the Anzac troops were decimated as they attempted to invade the Ottoman territory. In a clear miscalculation of the enemy's capacities and strategic advantage, the British command ordered the troops into a beach landing that made them easy 
targets for the Turkish artillery, which was positioned in the cliffs above the landing cove. Innumerable Anzac troops were slaughtered, many before they had even set foot on land. While this was an inglorious military defeat, it nevertheless marks the first major military campaign for the infant nations of Australia and New Zealand; the campaign is 'celebrated' in national holidays in both countries. However, as well as marking the military arrival of the Anzacs in global warfare, Gallipoli is also seen as the moment in which the limits of the 'mother country' and the ideals of the British Empire are exposed. Australians, in particular, have a paradoxical relationship with the former colonial 'mother'; Gallipoli demonstrated the need for some level of independent, national interest that may diverge from the interests and command of the imperial parent.

2. During the Australian gold rushes of the 1850s, the colonial government in Victoria sought to extract greater revenues from the diggers by imposing an excessively expensive fossickers licence. Australia's only significant armed political rebellion occurred at Ballarat in 1854, when miners constructed a stockade in order to resist these and other 'oppressive' laws. In the clashes that followed, around 22 miners and six soldiers were killed. The stockade is said to have laid the foundations for Australia's democracy movement.

\section{References}

Akerman, P. (2003) 'Remembering Bali', Sunday Telegraph (5 Oct.): 2.

Ali, T. (2003) The Clash of Fundamentalisms: Crusades, Jihads and Modernity (rev. edn). London: Verso.

Anderson, B. (1991) Imagined Communities: Reflections on the Origin and Spread of Nationalism (rev. edn). London: Verso.

Baudrillard, J. (1987) 'Forget Baudrillard', in Forget Foucault (trans.

P. Beitchmann, P.L. Hildreth and M. Polizzotti). New York: Semiotext(e).

Baudrillard, J. (1995) The Gulf War Did Not Take Place. Sydney: Power Publications.

Baudrillard, J. (2002) The Spirit of Terrorism and Requiem for the Twin Towers (trans. C. Turner). London: Verso.

Bok, S. (1998) Mayhem: Violence as Entertainment. New York: Perseus.

Carruthers, S. (2000) The Media at War: Communication and Conflict in the

Twentieth Century. London: Macmillan.

Castells, M. (1997) The Power of Identity. London: Blackwell.

Chomsky, N. (2001) September 11. Crows Nest, Sydney: Unwin.

Connor, L. and A. Vickers (2003) 'Crisis, Citizenship and Cosmopolitanism:

Living in a Local and Global Risk Society in Bali', Indonesia 75(April): 153-80.

Cribb, R. (ed.) (1990) The Indonesian Killings: 1960-1965. Clayton: Monash

University Centre for South-East Asian Studies.

Debord, G. (1995) Society of the Spectacle (trans. D. Nicholson-Smith). New

York: Zone Books.

Dubecki, L. (2003) 'Politicians Pay Tribute to Bali Victims', The Age (10 Oct.): 
Featherstone, M. (1995) Undoing Culture: Globalization, Postmodernism and Identity. London: Sage.

Foucault, M. (1991) 'Governmentality', in G. Burchell (ed.) The Foucault Effect: Studies in Governmentality, pp. 87-104. Chicago, IL: University of Chicago Press.

Hamilton, A. (1990) 'Fear and Desire: Aborigines, Asians and the National Imaginary', Australian Cultural History 9: 14-35.

Held, D. (1995) Democracy and the Global Order: From the Modern State to Cosmopolitan Governance. Cambridge: Polity Press.

Hitchcock, M. and D.N. Putra (2004) 'The Bali Bombings: Tourism Crisis Management and Conflict Avoidance', Current Issues in Tourism 7(4-5): 62-76.

Hoffman, B. (1998) Inside Terrorism. New York: Columbia University Press. Holland, K. (2002) 'Poem on the Bali Bombing', Zionist Federation Newsletter, 31(Nov.-Dec.). [Available at:http://www.zfa.com.au/]

Huntington, S. (1996) The Clash of Civilizations and the Remaking of World Order. New York: Simon \& Schuster.

Jameson, F. (1981)The Political Unconscious: Narrative as a Socially Symbolic Act. London: Methuen.

Laqueur, W. (1987) The Age of Terrorism. Boston, MA: Brown.

Laqueur, W. (2003) No End to War: Terrorism in the Twenty-First Century. New York: Continuum.

Lewis, B. and J. Lewis (2004) 'After the Glow: Community and Risk in the Context of the Bali Bombings', paper delivered at the Sources of Insecurity Conference, Melbourne, November.

Lewis, J. (1994) 'Putu Goes to Paris: Global Communication and Australian Imaginings of the East', Kunapipi 16(3): 46-60.

Lewis, J. (2002) Cultural Studies. London: Sage.

Lewis, J. (2003) 'The Electronic Polis: Media Democracy and the Invasion of Iraq', Reconstruction 3(3). [Accessed 26 December 2005:

http://www.reconstruction.ws/033/lewisbest.htm]

Lewis, J. (2005) Language Wars: The Role of Media and Culture in Global Terror and Political Violence. London: Pluto Press.

Nacos, B. (2002) Mass-Mediated Terrorism: The Central Role of the Media in Terrorism and Counter-Terrorism. London: Rowman and Littlefield.

Nairn, T. (2002) 'On the Modesty of Australia', Arena Magazine (Dec.): 32.

Norris, C. (1992) Uncritical Theory: Postmodernism, Intellectuals and the Gulf War. London: Lawrence \& Wishart.

Reuter, T. (ed.) (2003) Inequality, Crisis and Social Change in Indonesia: The Muted Worlds of Bali. London: Routledge-Curzon.

Silberstein, S. (2002) War of Words: Language, Politics and 9/11. London:

Routledge.

Smith, J. (2004) 'The Gnostic Baudrillard: A Philosophy of Terrorism Seeking

Pure Appearance', International Journal of Baudrillard Studies 1(2): 16-29.

'The No-Longer-Lucky Country' (2002) The Economist (12 Oct.): 32. 
Tuman, J. (2003) Communicating Terror: The Rhetorical Dimension of Terrorism. Thousand Oaks, CA: Sage.

United Nations Development Program (UNDP) (2003) Bali Beyond the

Tragedy: Impact and Challenges for Tourism-Led Development in Indonesia.

Denpasar: Consultative Group Indonesia, UNDP and the World Bank.

Vickers, A. (1990) Bali: Paradise Created. Ringwood: Penguin.

Vickers, A. (2003) 'Being Modern in Bali after Suharto', in T. Reuter (ed.)

Inequality, Crisis and Social Change in Indonesia: The Muted Worlds of Bali, pp. 17-29. London: Routledge-Curzon.

Virilio, P. (2002) Desert Screen: War at the Speed of Light (trans. M. Degener).

New York: Continuum.

Zolo, D. (1997) Cosmopolis: Prospects for World Government (trans. D. McKie).

Cambridge: Polity Press.

\section{Biographical note}

Jeff Lewis is Associate Dean (Research) in the Portfolio of Design and Social Context at RMIT University, Australia. He researches and teaches in cultural and media studies and has written widely on cultural issues and cultural theory, including a major international text, Cultural Studies (Sage, 2002). Over recent years he has been actively engaged in writing and public speaking on the Middle East conflicts and the mediation of terror and terrorism. Currently he is researching the role of the media in global modes of political violence. ADDRESs: RMIT University, GPO Box 2476V, 3001 Melbourne, Australia. [email: jeff.lewis@rmit.edu.au] 